\title{
Seasonal Climate Associated with Major Shipping Routes in the North Pacific and North Atlantic
}

\author{
Jau-Ming Chen ${ }^{1, *}$, Pei-Hua Tan ${ }^{2}$, Chih-Min Hsieh ${ }^{1}$, Jin-Shuen Liu ${ }^{1}$, Hui-Shan Chen ${ }^{2}$, Li-Hua Hsu ${ }^{1}$, and \\ Jun-Leng Huang ${ }^{1}$ \\ ${ }^{1}$ Department of Maritime Information and Technology, National Kaohsiung Marine University, Taiwan \\ ${ }^{2}$ Department of Applied History, National Chiayi University, Taiwan
}

Received 4 July 2013, accepted 31 December 2013

\begin{abstract}
The major shipping routes in the North Pacific (NP) and North Atlantic (NA) are analyzed via ship-reported records compiled by the International Comprehensive Ocean-Atmosphere Data Set (ICOADS). The shipping route seasonal characteristics and associated climatic features are also examined. In the NP, the dominant cross-basin route takes a great-circle path between East Asia and North America along $54^{\circ} \mathrm{N}$ north of the Aleutian Islands throughout the year. This route penetrates the Aleutian low center where ocean waves and winds are relatively weaker than those in the low's southern section south of $50^{\circ} \mathrm{N}$. Moreover, the Earth's spherical shape makes a higher-latitude route shorter in navigational distance across the NP than a lower-latitude route. Two additional mid-latitude routes through the $40^{\circ}-50^{\circ} \mathrm{N}$ region appear in summer when the Aleutian low vanishes. In the NA, the major shipping routes form an X-shaped pattern in the oceans south of $40^{\circ} \mathrm{N}$ to connect North America/the Panama Canal and the Mediterranean Sea/the British Isles and Europe. These major shipping routes are far from the influence of the Icelandic low and thus are used throughout the year due to the stability in marine conditions and their general efficiency. A third and more zonal route appears to the north of the $\mathrm{X}$-shaped routes in the $40^{\circ}-50^{\circ} \mathrm{N}$ region. Weak influence from the Icelandic low on marine conditions during summer and spring means that more ships take this route in summer and spring than in winter and fall.
\end{abstract}

Key words: Seasonal climate, Shipping routes, North Pacific, North Atlantic

Citation: Chen, J.M., P. H.Tan, C.M.Hsieh, J. S. Liu, H. S. Chen, L. H. Hsu, and J.L. Huang, 2014: Seasonal climate associated with major shipping routes in the North Pacific and North Atlantic. Terr. Atmos. Ocean. Sci., 25, 381-400, doi: 10.3319/TAO.2013.12.31.01(A)

\section{INTRODUCTION}

Environmental observation systems are dense over lands, but relatively rare over the oceans. This relates primarily to the high costs involved in operation and maintenance of in-situ marine observation structures. Oceans and the atmosphere have a highly interactive climate system. Good coverage of marine observations would be of help in climate research, marine navigation, marine safety and naval operations (e.g., Woodruff et al. 2005). Satellite remote sensing provides one means of improving marine observations. However, some surface variables, including air temperature and near-surface humidity, cannot be reliably measured by satellite (e.g., Kent et al. 2007). Moreover, polar-orbiting satellites have limited regional coverage. They are generally only

\footnotetext{
* Corresponding author

E-mail:cjming@mail.nkmu.edu.tw
}

able to observe particular regions once every 10 - 20 days. Such low temporal coverage makes satellite-derived information suitable only for case study analyses. More data are needed for comprehensive large-scale weather and climate process studies.

Motivated by the need to improve marine observations, significant efforts have been made to compile surface meteorological observations from voluntary observation ships, fixed and drifting buoys and ocean stations. The collected data are referred to as the International Comprehensive Ocean-Atmosphere Data Set (ICOADS; e.g., Parker et al. 2004; Woodruff et al. 2005; Worley et al. 2005). So far, ICOADS data are able to provide long-term marine observation data dating back to 1784 . This dataset is far more substantial than that provided by satellite and other observational sources. ICOADS spatial coverage extends to all of 
the oceans of the globe. The data are systematically screened to ensure quality. As such, the data are widely used as foundation data for many blended analyses and reanalyses (e.g., Kalnay et al. 1996; Smith and Reynolds 2003, 2004; Rayner et al. 2003). ICOADS data characteristics have been studied by previous researches. Worley et al. (2005) pointed out that instrument-measured variables (e.g., sea-level pressure, surface wind and others) are generally more reliable than those obtained by visual estimates (e.g., ocean waves, clouds and others). In the visual field, Laing (1985) compared shipreported wave heights with measurements and concluded that the reported data captured the physical characteristics of wave fields well and thus can be useful in climatological studies. Gulev and Hasse (1998) and Gulev et al. (2003) derived North Atlantic (NA) and global wave climatology studies from ICOADS observations. Generally speaking, the accuracy of individual ship observations is not consistently high, but they remain an important source of gross information over oceans (e.g., Kent et al. 2007).

The majority of ICOADS data comes from routinelyrecorded ship logs (e.g., Worley et al. 2005). Log reports provide relatively accurate information describing the spatial and temporal movement of a ship during its passage over oceans. Accordingly, major shipping routes over oceans and their variability can be systematically investigated from these records. Chen et al. (2012) employed ICOADS data to examine the possible impacts of El Niño and Southern Oscillation (ENSO; e.g., Rasmusson and Carpenter 1982; Rasmusson and Wallace 1983; Philander 1990) on wintershipping variability across the North Pacific (NP). Their analyses revealed that in the northern NP, where major cross-Pacific routes are located, total shipping frequency exhibits a dominant variability feature on an interdecadal time scale and a secondary feature on an interannual time scale associated with ENSO. Dominant interdecadal variability is closely related to international trade between East Asian countries and the USA. For interannual variability, El Niño events cause the Aleutian low to deepen and displace eastward (e.g., Horel and Wallace 1981; Wallace and Gutzler 1981; Fritz 1982, 1985; Shukla and Wallace 1983), leading to suppressed ocean waves in the low's northern section by anomalous easterly flows. Weakened ocean waves provide better marine environments to facilitate shipping efficiency, resulting in decreased navigational times. Shipping frequency represented by the number of ship reports thus tends to decrease in an El Niño winter. As a result, the interannual components of Niño-3.4 sea surface temperatures and shipping frequency over the major cross-Pacific shipping routes north of the Aleutian Islands have a negative correlation. Gulev and Hasse (1999) and Gulev and Grigorieva (2006) examined the interannual variability of wind waves and swells in the NA and NP. They found that wind wave variability is closely connected with local wind speed, while swell changes are associated with variability in cyclone counts.
The above reviews demonstrate that ICOADS data can properly portray the interannual variability of marine environments in the NP and NA. In view of this result, it is reasonable to anticipate that ICOADS data can also suitably delineate the seasonal features of marine environments and shipping activity in these oceans. As mentioned previously, the most reliable ICOADS data ought to be the spatial location of ships and report numbers. The spatial distribution of ship positions and total number of reports can be employed to depict major shipping routes. However, ICOADS data application in seasonal shipping activity has not been comprehensively studied. The main purpose of this study is to analyze the characteristics of major shipping routes in the NP and NA and associated seasonal climatic factors. Major questions raised in this study are as follows:

(1) What are the major seasonal characteristics of marine climatic conditions and shipping routes in the NP and NA depicted by ICOADS data?

(2) What are the major climatic features affecting seasonal shipping routes in the NP and NA?

(3) How does synoptic weather affect major shipping routes?

The results of this study should provide a better understanding of shipping activity and associated climate environments over the NP and NA. This understanding should be beneficial for maritime safety, the shipping industry and marine meteorological research. The study regarding the relationship between seasonal climatic conditions and major shipping routes may be interpreted as a benchmark for the quality of ICOADS data.

\section{DATA}

Two datasets are analyzed in this study. The first is the National Centers for Environmental Prediction/Climate Forecast System Reanalysis (NCEP/CFSR) data (Saha et al. 2010). Its 10-m wind (V10) fields in a T382 Gaussian (about $0.3125^{\circ} \times 0.3125^{\circ}$ ) grid and sea level pressure (SLP) fields in a $0.5^{\circ} \times 0.5^{\circ}$ grid are used to delineate surface circulation features. The second set of data is ICOADS data, which are compiled from the observations of ships, buoys and ocean stations. Such a diverse range of sources plus different measurement methods and recording practices jointly result in inhomogeneous data quality throughout the period of collected records (e.g., Minobe and Maida 2005). In order to specifically depict major shipping routes, the analysis includes only reports from ships. Generally for quality control, a value of 2.5 to 4.5 standard deviations is commonly used as the threshold to filter outliers from monthly or seasonal grid data (e.g., Gulev and Grigorieva 2006; Tokinaga et al. 2009). A threshold of 3.5 standard deviations is applied in the present study. This is the same standard used in the monthly ICOADS data statistics (e.g., Worley et al. 2005). Observational data collected more recently are more reliable due to more coherent and accurate sampling processes (e.g., 
Worley et al. 2005). To reduce the uncertainty-regarding data quality, data from the past three decades are employed to conduct climatological analyses. The analysis data spans from 1981 to 2010. To provide a uniform spatial distribution pattern the ICOADS variables are converted to a $2^{\circ} \times 2^{\circ}$ grid in the NP and NA.

\section{MAJOR SHIPPING ROUTES IN THE NORTH PACIFIC}

Chen et al. (2012) delineated shipping routes in terms of the frequency patterns of accumulated ship-report numbers throughout an individual season. This approach is adopted in this study to analyze major shipping routes. The climatological (1981 - 2010) means of accumulated frequency patterns in the NP for winter (DJF), spring (MAM), summer (JJA), and fall (SON) are shown in Fig. 1. As indicated by large frequency patterns $(\geq 60)$, the major shipping routes in winter (Fig. 1a) follow a great circle across the NP. The dominant route from Asia to America emanates from the coasts of East Asia and Japan. It then heads northeastward along the Kuril Islands and turns eastward at a point southeast of the Russian Kamchatka Peninsula. The eastbound course moves mainly along the oceans at $54^{\circ} \mathrm{N}$ which are north of the Aleutian Islands. These routes connect to the western coastlines of North America and further onward to the Panama Canal in Central America. This great-circle route also dominates in spring, summer, and fall. It appears as the most popular cross-Pacific route throughout the year. In summer (Fig. 1c), two additional cross-NP routes appear in a more southern region around $40^{\circ}-50^{\circ} \mathrm{N}$. In the $180^{\circ}-140^{\circ} \mathrm{W}$ regions, one eastbound route moves eastward along $50^{\circ} \mathrm{N}$, while the other route moves southeastward from $46^{\circ}$ to $42^{\circ} \mathrm{N}$. It is interesting to investigate climatic factors favorable to the existence of the dominant great-circle route all year around and the two additional routes in summer.

\section{SEASONAL CLIMATE IN THE NORTH PACIFIC}

Marine environments are illustrated using the climatological means of seasonal ocean waves (represented by wind sea parameter of ICOADS data) in Fig. 2. Overall, ocean waves are stronger at higher latitudes than lower latitudes. By zonal distribution, waves in the central NP are stronger than those in the eastern and western NP. In the central-NP region $\left(160^{\circ} \mathrm{E}-160^{\circ} \mathrm{W}, 40^{\circ}-60^{\circ} \mathrm{N}\right)$, seasonal-mean ocean waves reach a height of $2.5-3 \mathrm{~m}$ in winter, $2-2.5 \mathrm{~m}$ in spring and fall, and only $1-1.5 \mathrm{~m}$ in summer. The NP waves are enhanced in winter and weakened in summer. These features are consistent with the climatological patterns shown by Gulev et al. (2003). The major tracks of the great-circle route to the north of $50^{\circ} \mathrm{N}$ indicated in Fig. 1 are superimposed on Fig. 2 for comparison. It is clear to see that the great-circle route tends to move away from the maximum centers of ocean waves in the central NP south of $50^{\circ} \mathrm{N}$ in winter, spring and fall. Such a route provides an efficient and safe way to cross the NP.

The atmospheric climatic features associated with wave patterns are investigated via the surface circulation depicted by CFSR sea level pressure (SLP) and 10-m winds $(V 10)$. As shown in Fig. 3, the winter surface pressure features the dominant Aleutian low in the northern NP (e.g., Terada and Hanzawa 1984; Fritz 1985; Zhang et al. 2004; Ahren 2005; Rodionov et al. 2005), with its center overlying the Aleutian Islands. The Aleutian low also dominates in the northern NP during spring and fall, but vanishes in summer. The spatial distributions and intensity of the Aleutian low in different seasons are interpreted from the positions and pressure values of the SLP minimum centers in the northern NP $\left(160^{\circ} \mathrm{E}-140^{\circ} \mathrm{W}, 40^{\circ}-60^{\circ} \mathrm{N}\right)$. As shown in Table 1 , the Aleutian low center emerges in fall at higher latitude $\left(1003.3 \mathrm{hPa}\right.$ at $\left.58^{\circ} \mathrm{N}\right)$, reaches maximum intensity with a southwestward extension in winter $\left(997 \mathrm{hPa}\right.$ at $\left.51.5^{\circ} \mathrm{N}\right)$, and weakens and retreats northeastward in spring $(1007.3 \mathrm{hPa}$ at $55.5^{\circ} \mathrm{N}$ ). The great-circle route indicated by thick dashed lines in Fig. 3 reveals that the major shipping routes tend to sail through the central regions of the Aleutian low in winter, spring and fall. In this region, the decreased pressure gradient results in weaker winds and waves, providing safer marine environments.

The 10-m wind fields shown in Fig. 4 reveal the dominance of a cyclonic circulation (i.e., the Aleutian low) in the middle- and higher-latitude zones of the NP in winter, spring, and fall. In winter (Fig. 4a), the climatological westerly flows $\left(\geq 3 \mathrm{~m} \mathrm{~s}^{-1}\right)$ appear at the southern section of the Aleutian low. They extend from $140^{\circ} \mathrm{E}$ to $140^{\circ} \mathrm{W}$ along the $40^{\circ} \mathrm{N}$ latitude in winter. The strong winds shift northward to the $40^{\circ}-50^{\circ} \mathrm{N}$ zone in a more eastward zone between $170^{\circ} \mathrm{E}$ and $140^{\circ} \mathrm{W}$ in spring and across the entire northern NP in fall. The northward-displaced strong winds are accompanied by the northeastward shift of the Aleutian low center in spring and fall (see Fig. 3). The Aleutian low's pressure system and the strong and cold westerly flows at the low's southern section are responsible for high waves over the central NP south of the Aleutian Islands. The above major westerly flows spatially correspond well with the major centers of ocean waves in Fig. 2, showing a southward displacement in winter, an eastward displacement in spring, and a northward displacement in fall. On the other hand, the winds are weaker in the regions near the Aleutian low center, which are to the north of the Aleutian Islands. These relatively safe conditions lead to the major great-circle shipping routes taking a path along $54^{\circ} \mathrm{N}$ latitude, as shown by the thick dashed lines in Fig. 4. In the regions, northeasterly or northerly flows dominate in winter, spring, and fall. In summer, the Aleutian low vanishes while the northern NP is affected by the Pacific subtropical high (Fig. 4c). In the mid-latitudes, the warm southwesterly/southerly flows and high pressure system of the Pacific 

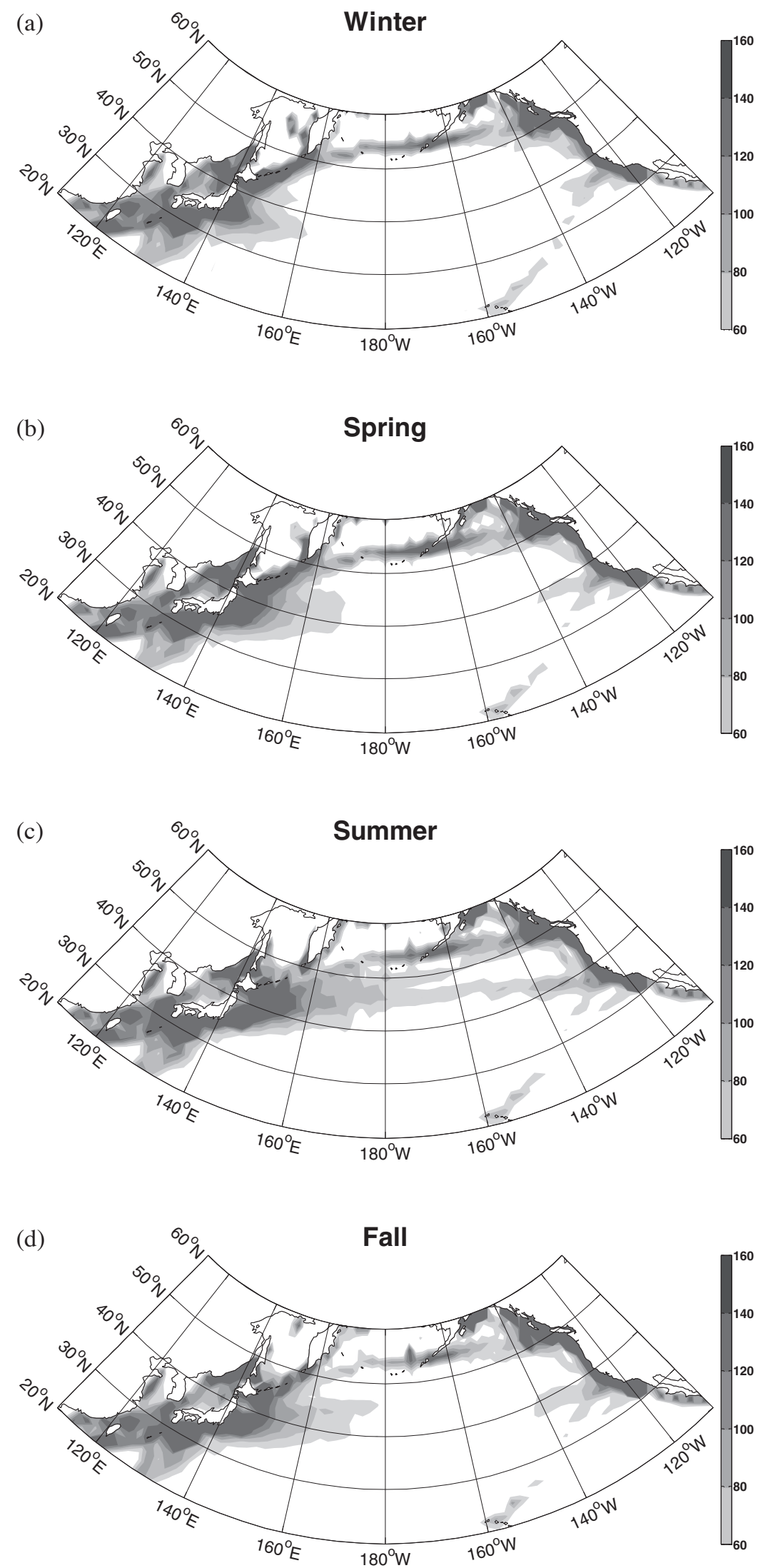

Fig. 1. The climatological-mean (1981 - 2010) shipping frequency in the NP represented by accumulated number of ship reports throughout the season from ICOADS data for (a) winter (DJF), (b) spring (MAM), (c) summer (JJA), and (d) fall (SON). 

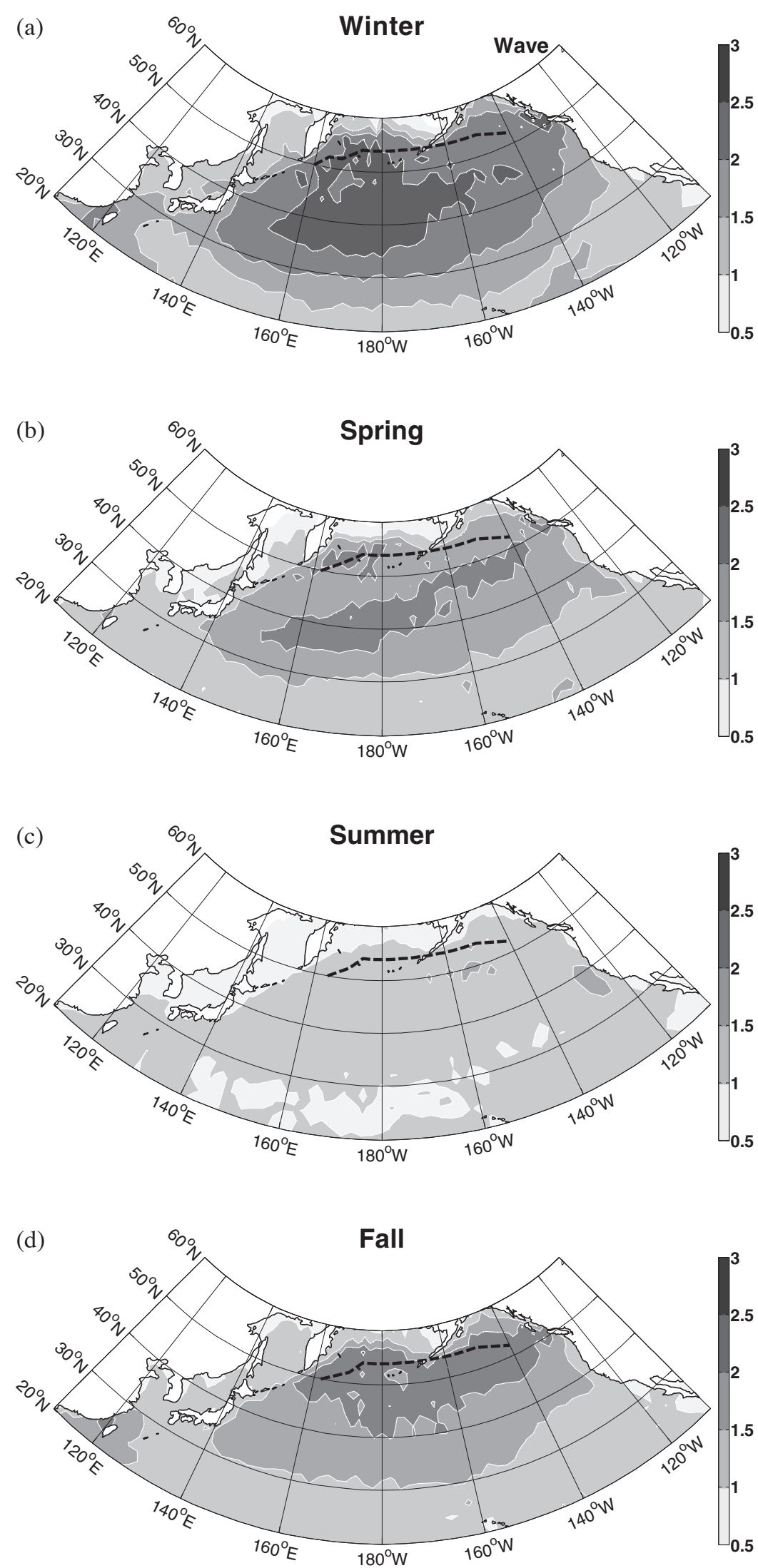

Fig. 2. As in Fig. 1, except for the climatological-mean ocean wave in the NP computed from ICOADS data for (a) winter, (b) spring, (c) summer, and (d) fall. The contour intervals are $0.5 \mathrm{~m}$. The thick dashed lines represent the major great-circle routes to the north of $50^{\circ} \mathrm{N}$ indicated in Fig. 1 . 

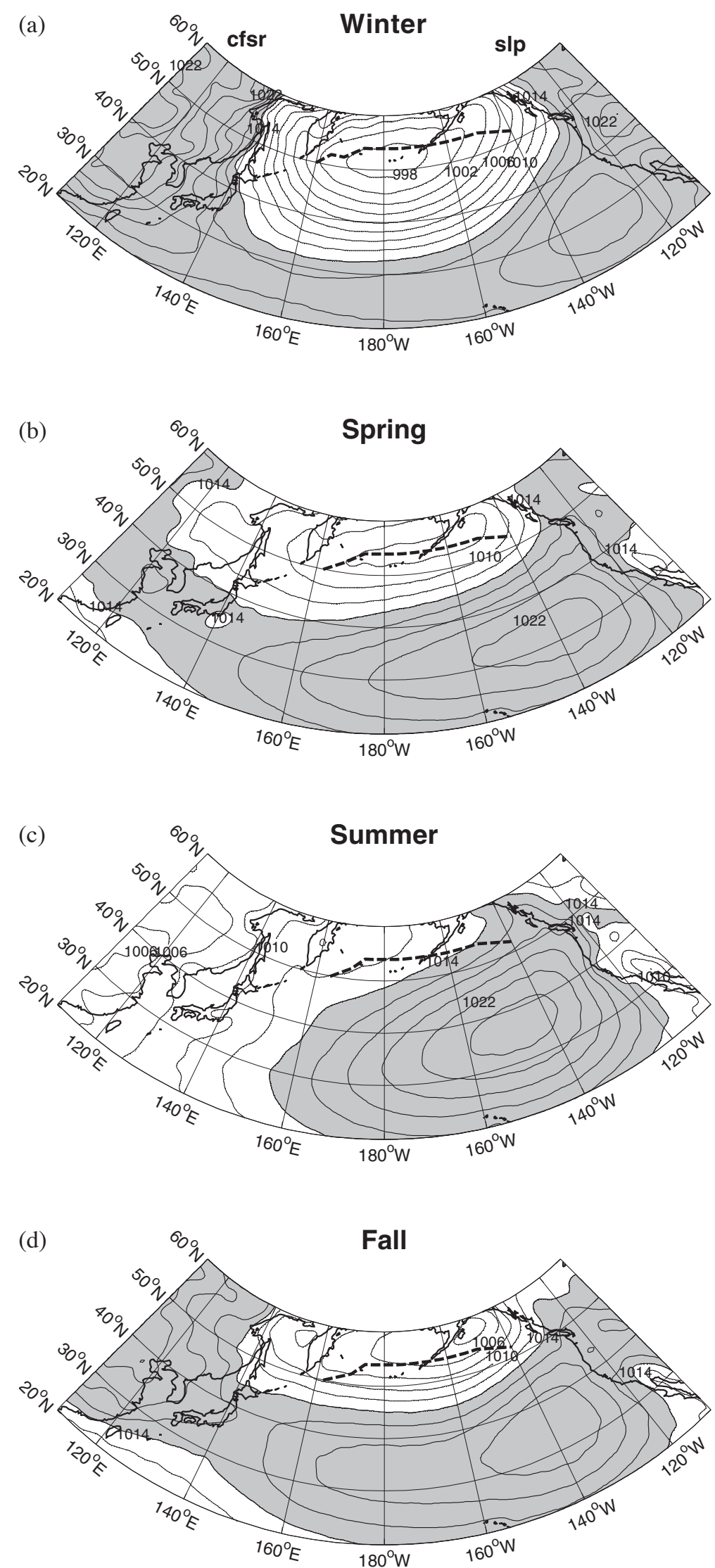

Fig. 3. As in Fig. 1, except for the climatological-mean SLP in the NP computed from CFSR data for (a) winter, (b) spring, (c) summer, and (d) fall. Pressure values larger than $1014 \mathrm{hPa}$ are shaded. The contour intervals are $2 \mathrm{hPa}$. The thick dashed lines represent the major great-circle routes to the north of $50^{\circ} \mathrm{N}$ indicated in Fig. 1 . 
Table 1. The positions and pressure values of SLP minimum centers over the northern sections of the NP and NA.

\begin{tabular}{c|c|c|c|c}
\hline \multirow{2}{*}{ season } & \multicolumn{2}{|c|}{ North Pacific $\left(\mathbf{1 6 0}^{\circ} \mathrm{E}-\mathbf{1 4 0}^{\circ} \mathbf{W}, \mathbf{4 0}^{\circ} \mathbf{- 6 0 ^ { \circ }} \mathbf{N}\right)$} & \multicolumn{2}{c}{ North Atlantic $\left(\mathbf{6 0}^{\circ} \mathbf{W}-\mathbf{0}^{\circ}, \mathbf{5 0}^{\circ}-\mathbf{7 0}^{\circ} \mathbf{N}\right)$} \\
\cline { 2 - 5 } & position & pressure $(\mathbf{h P a})$ & position & pressure (hPa) \\
\hline fall & $149^{\circ} \mathrm{W}, 58^{\circ} \mathrm{N}$ & 1003.3 & $27^{\circ} \mathrm{W}, 62.5^{\circ} \mathrm{N}$ & 1002.6 \\
\hline winter & $180^{\circ} \mathrm{W}, 51.5^{\circ} \mathrm{N}$ & 997.0 & $37.5^{\circ} \mathrm{W}, 61.5^{\circ} \mathrm{N}$ & 995.3 \\
\hline spring & $153^{\circ} \mathrm{W}, 55.5^{\circ} \mathrm{N}$ & 1007.3 & $35.5^{\circ} \mathrm{W}, 61.5^{\circ} \mathrm{N}$ & 1006.9 \\
\hline summer & $160^{\circ} \mathrm{E}, 56^{\circ} \mathrm{N}$ & 1010.0 & $27^{\circ} \mathrm{W}, 62.5^{\circ} \mathrm{N}$ & 1009.1 \\
\hline
\end{tabular}
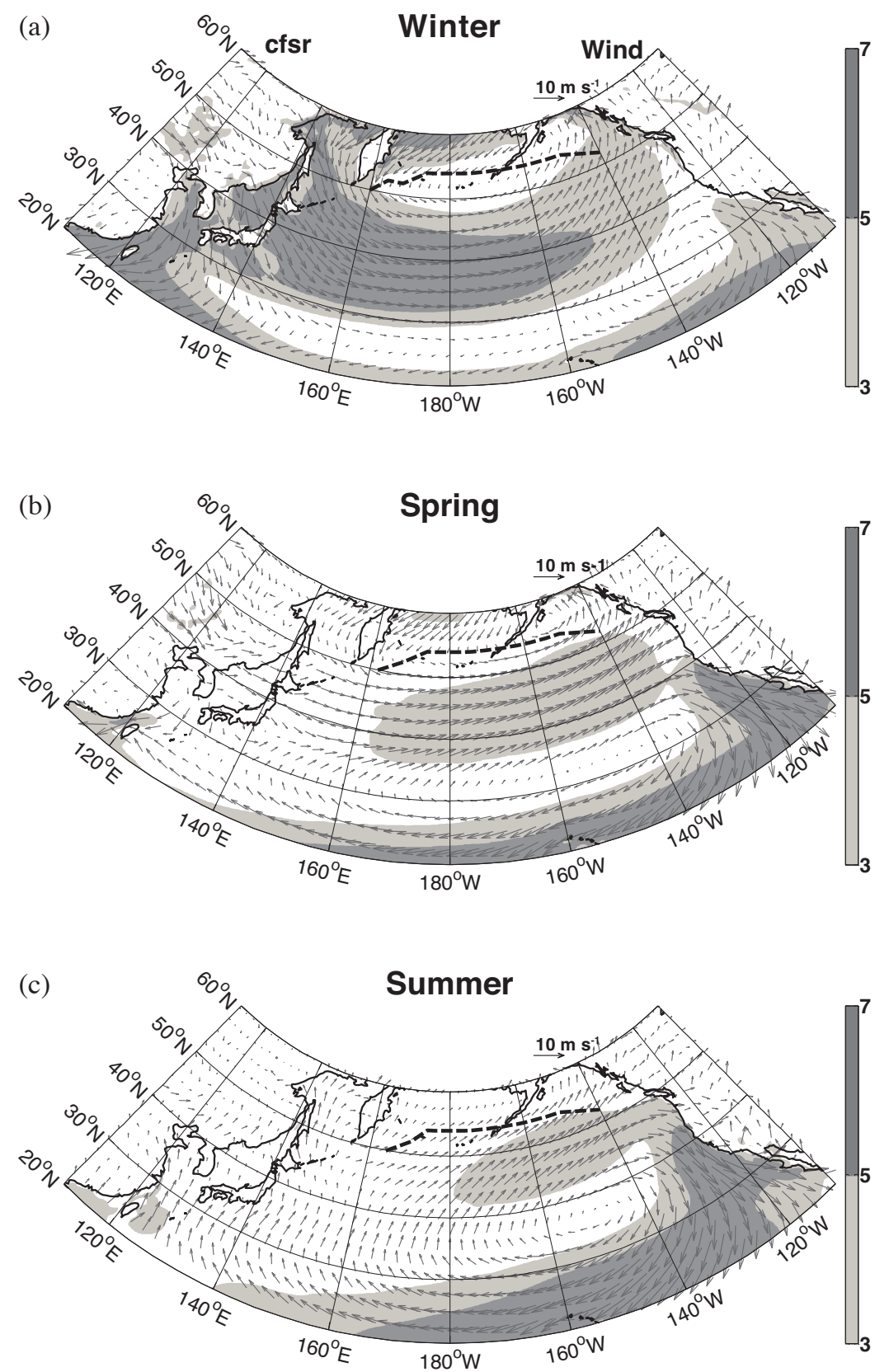

Fig. 4. As in Fig. 3, except for the climatological-mean 10-m winds (vector) and their speed (shading) in the NP computed from CFSR data for (a) winter, (b) spring, (c) summer, and (d) fall. The shading has the intervals of $2 \mathrm{~m} \mathrm{~s}^{-1}$. The thick dashed lines represent the major great-circle routes to the north of $50^{\circ} \mathrm{N}$ indicated in Fig. 1 . 


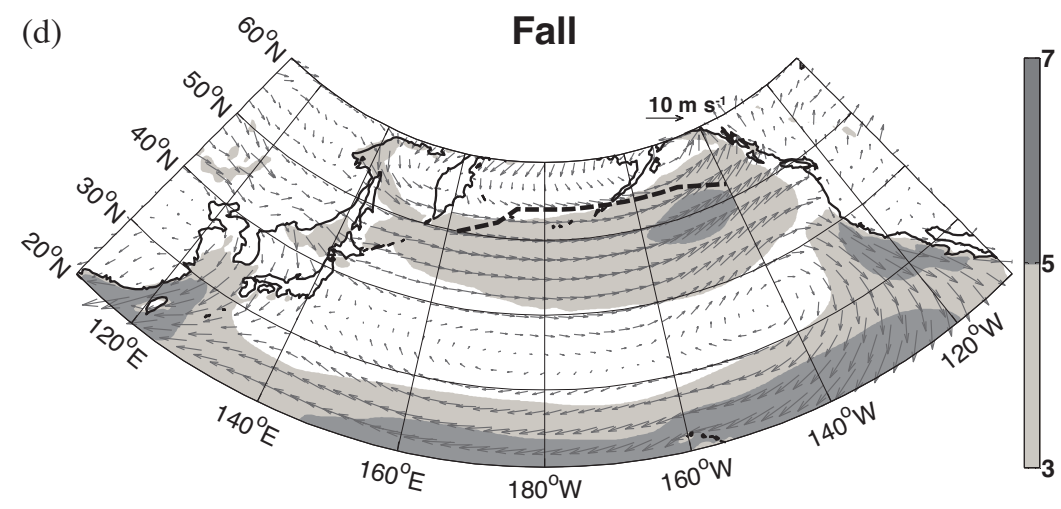

Fig. 4. (Continued)

subtropical high correspond to weakened surface winds and ocean waves. Given the weak winds and waves, two additional cross-NP routes appear in the $40^{\circ}-50^{\circ} \mathrm{N}$ zone south of the Aleutian Islands (see Fig. 1d) in accordance with the safe mid-latitude marine environments.

The above spatial correspondence in meridional displacements of strong ocean waves, the Aleutian low center and major westerly flows indicates that the marine environments depicted by ICOADS data are consistent with atmospheric features portrayed by CFSR data. This consistency serves to validate the quality of ICOADS data in delineating marine climatological features. ICOADS data are further employed to quantitatively demonstrate advantages in navigational safety and efficiency provided by taking the great-circle routes north of the Aleutian Islands compared to a more southerly passage affected by westerly flows. Wave characteristics over the central-NP shipping routes to the north $\left(180^{\circ}-160^{\circ} \mathrm{W}, 52^{\circ}-56^{\circ} \mathrm{N}\right)$ and south $\left(180^{\circ}-160^{\circ} \mathrm{W}\right.$, $44^{\circ}-48^{\circ} \mathrm{N}$ ) of the Aleutian Islands are shown in Fig. 5. In the southern route along the $44^{\circ}-48^{\circ} \mathrm{N}$ zone, the chances of weak waves $(\leq 2 \mathrm{~m})$ are $35 \%$ in winter, $41 \%$ in spring, $74 \%$ in summer, and $50 \%$ in fall (Figs. $5 \mathrm{a}, \mathrm{c}, \mathrm{e}$, and g). It is clear that ocean waves reduce significantly during summer in the regions south of the Aleutian Islands. More ships thus take those two additional routes in this region to cross the NP in summer. Along the northern route at $54^{\circ} \mathrm{N}$, weak waves ( $\leq$ $2 \mathrm{~m}$ ) account for $46 \%$ of total waves in winter, $59 \%$ in spring, $78 \%$ in summer, and $54 \%$ in fall (Figs. $5 \mathrm{~b}, \mathrm{~d}, \mathrm{f}$, and $\mathrm{h}$ ). The chance of weak waves increases by $11 \%$ from the southern route to the northern route in winter, by $18 \%$ in spring, and by $4 \%$ in summer and fall. It is clear that the great-circle route north of the Aleutian Islands has safer marine conditions than the route south of these islands. As discussed previously, the $54^{\circ} \mathrm{N}$ route moves through or nearby the center of the Aleutian low in winter, spring and fall. Relatively weak winds produce weak ocean waves in this region compared with the southern route which is affected by cold mid-latitude westerly flows. In addition, the navigational distance along the $54^{\circ} \mathrm{N}$ great-circle route is shorter than via the lower latitudes due to the Earth's spherical shape, saving navigational time and costs plus providing a relatively safe marine environment.

One additional important factor affecting navigation safety in cross-NP shipping is the degree and frequency of severe weather. With the seasonal march of surface circulations, synoptic weather is affected by seasonal climatic conditions, exhibiting noticeable seasonality. Synoptic weather characteristics in the mid-latitudes can be measured by transient activity (e.g., Blackmon et al. 1977; Blackmon and Lau 1980; Blackmon et al. 1984), which is computed as the root mean square (RMS) of 2-7-day filtered SLP throughout each season. Stronger transient activity indicates more severe weather. The RMS patterns of synoptic weather for the four seasons are shown in Fig. 6. Overall, the RMS patterns exhibit a maximum center in the central NP with different spatial coverage and intensity. In winter (Fig. 6a) the maximum RMS center ( $\geq 5 \mathrm{hPa}$ ) elongates over the central $\mathrm{NP}$ with a meridional extent across the $40^{\circ}-58^{\circ} \mathrm{N}$ zone. In spring (Fig. 6b) the maximum RMS center shrinks somewhat and extends southwest-northeasterly across the $42^{\circ}-54^{\circ} \mathrm{N}$ zone. In fall (Fig. 6d) it displaces northward to situate over the $46^{\circ}-60^{\circ} \mathrm{N}$ zone. In summer (Fig. 6c) the RMS patterns decrease significantly in intensity with a maximum value only around $3 \mathrm{hPa}$, clearly smaller than $5 \mathrm{hPa}$ in the other three seasons. The above comparisons indicate that transient activity in the central NP intensifies under the influence of the Aleutian low and weakens when affected by the Pacific subtropical high. Also revealed is that synoptic weather over the central NP tends to be safer for shipping in summer due to less rigorous transient activity than in the other three seasons. These results provide additional explanation for the appearance of two further cross-NP shipping routes in summer over the $40^{\circ}-50^{\circ} \mathrm{N}$ zone.

\section{MAJOR SHIPPING ROUTES IN THE NORTH ATLANTIC}

The seasonal shipping route patterns in the NA are 
shown in Fig. 7. Shipping is most active along the east coast of North America and the west coast of Europe and North Africa, showing heavy meridional transportation along the coastlines. The major cross-NA shipping routes appear in the $50^{\circ}-20^{\circ} \mathrm{W}$ zone and are largely restricted to the south of $50^{\circ} \mathrm{N}$. In this region the major crossing routes exhibit two tracks oriented southwest-northeasterly and northwestsoutheasterly to form an X-shaped pattern in the oceans south of $40^{\circ} \mathrm{N}$. As shown in Fig. 7 these two X-shaped routes appear throughout the year and exhibit a common point around $30^{\circ} \mathrm{W}, 38^{\circ}-40^{\circ} \mathrm{N}$. In spring (Fig. $7 \mathrm{~b}$ ), to the northwest of the common point the major shipping routes extend from the east coast of North America eastward along the $40^{\circ}-48^{\circ} \mathrm{N}$ zone and move southeastward toward the common point after $40^{\circ} \mathrm{W}$. To the southwest of the common point the predominant route starts from about $70^{\circ} \mathrm{W}, 20^{\circ} \mathrm{N}$ and moves northeastward directly to the common point. This route connects mainly southward to the Panama Canal. To the east of the common point the route in the southern portion connects eastward to the Mediterranean Sea via the Strait of Gibraltar. This route also merges with meridional coastal routes along Europe and Africa in regions $10^{\circ}-16^{\circ} \mathrm{W}, 32^{\circ}-40^{\circ} \mathrm{N}$. The route to the northeast of the common point connects northeastward to the British Isles and Europe, and further extends to the Baltic Sea and the Norwegian Sea. The above four tracks of the X-shaped pattern can be clearly identified in the
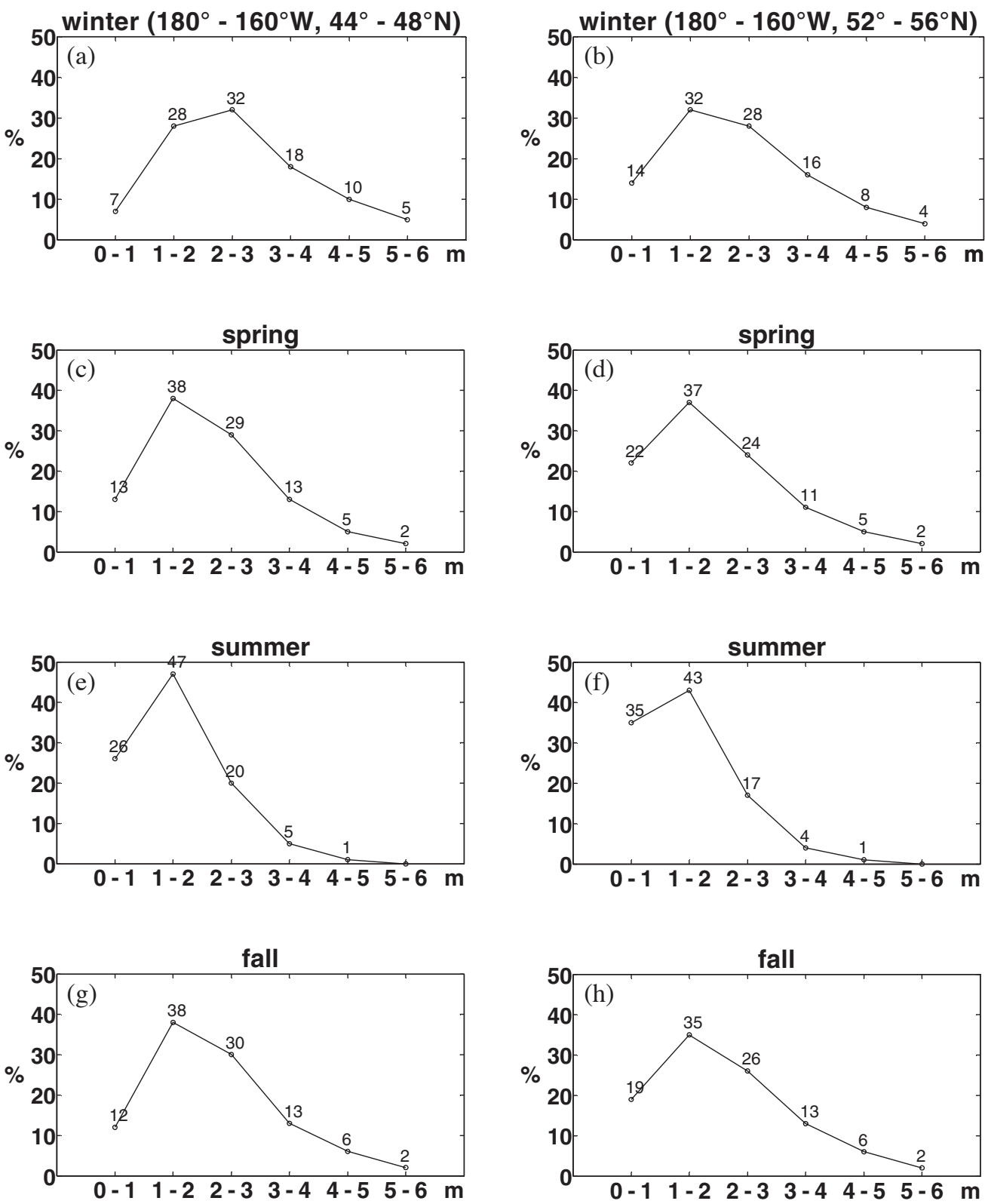

Fig. 5. The ocean wave distribution patterns at different height levels at two oceanic regions: along (left column) and to the south (right column) of the great-circle routes in the NP. The distributions are computed for each of the four seasons. 



Fig. 6. As in Fig. 3, except for the RMS values of 2-7-day filtered SLP fields in the NP computed from CFSR data for (a) winter, (b) spring, (c) summer, and (d) fall. The contour intervals are $1 \mathrm{hPa}$. 

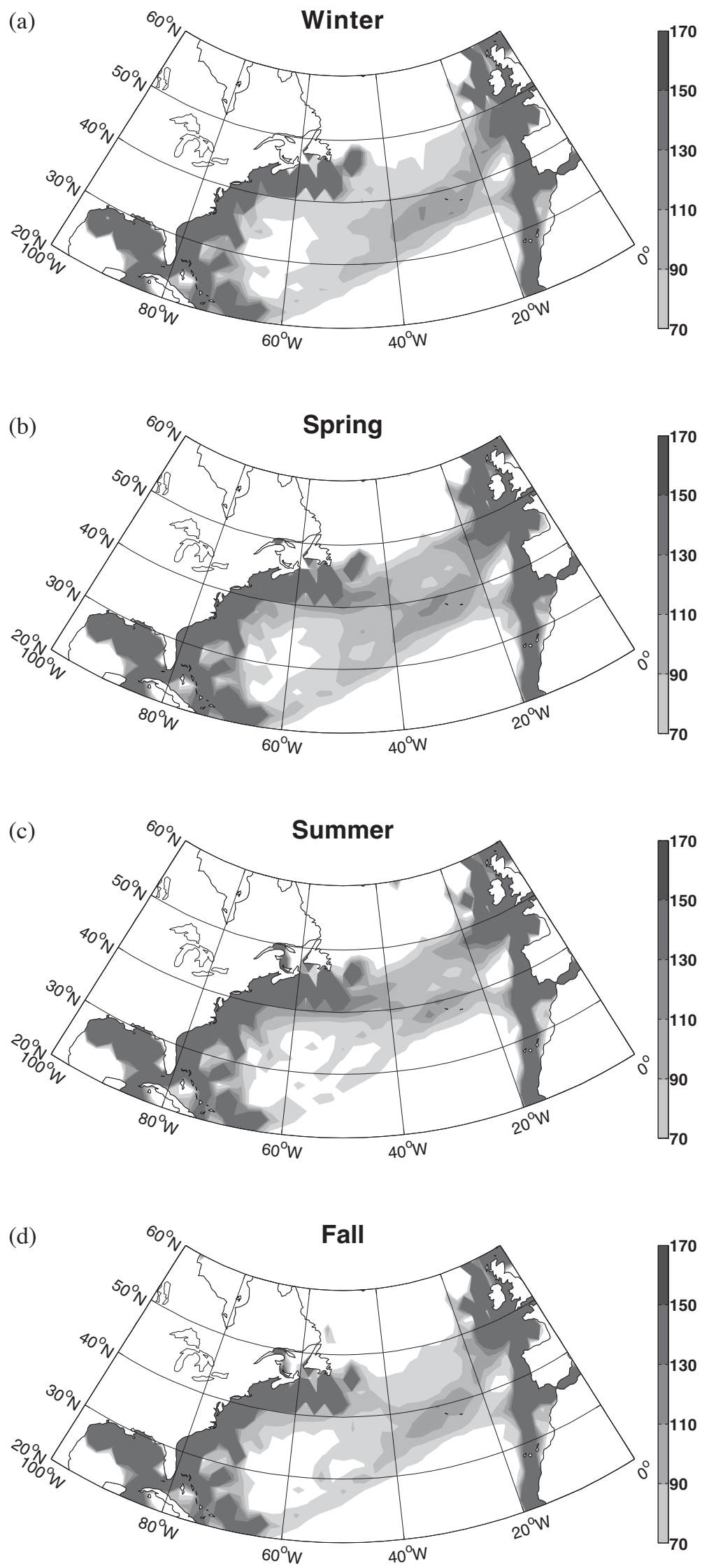

Fig. 7. The climatological-mean (1981 - 2010) shipping frequency in the NA represented by accumulated number of ship reports throughout the season from ICOADS data for (a) winter (DJF), (b) spring (MAM), (c) summer (JJA), and (d) fall (SON). 
major shipping routes in each season in Fig. 7.

In addition to the prevailing $\mathrm{X}$-shaped routes, there is a third and relatively zonal route in the $20^{\circ}-40^{\circ} \mathrm{W}, 40^{\circ}-50^{\circ} \mathrm{N}$ region. In this region the frequency contour is around 70 in winter and fall, but 90 in spring and summer. This increased frequency suggests that in spring and summer more ships tend to sail zonally between North America and West Europe via an east-west route to the north of $42^{\circ} \mathrm{N}$. However, as indicated by a frequency value larger than 70 , this route is considered a regular route throughout the year. In other words, marine conditions are not dangerous enough to be prohibitive of shipping in winter and fall. As such, it is a regular route, rather than an additional route during summer. This result is different from that found in the NP which exhibits two additional routes that only appear in summer (see Fig. 1c).

\section{SEASONAL CLIMATE IN THE NORTH ATLANTIC}

Seasonal climatic features associated with the NA shipping routes are first examined from ocean wave patterns depicted by ICOADS data. As shown in Fig. 8, seasonalmean waves are stronger in the oceans north of $40^{\circ} \mathrm{N}$ than those to the south. In the $20^{\circ}-50^{\circ} \mathrm{W}, 40^{\circ}-60^{\circ} \mathrm{N}$ regions, the winter-mean waves (Fig. 8a) reach a height of $2-3 \mathrm{~m}$. The strong waves extend southward and southwestward from the northern NA toward the oceans off the east coast of North America. The above northeast-southwest oriented wave pattern also appears in other seasons, but with less intensity. In the $20^{\circ}-50^{\circ} \mathrm{W}, 40^{\circ}-60^{\circ} \mathrm{N}$ regions, waves exhibit a magnitude of $1.5-2.5 \mathrm{~m}$ in spring (Fig. 8b) and fall (Fig. 8d), and $1-2 \mathrm{~m}$ in summer (Fig. 8c). The patterns discussed above reveal that the seasonal ocean waves across the NA are smallest in summer and smaller in the regions south of $40^{\circ} \mathrm{N}$ than to the north. The spatial distribution demonstrates that the dominant X-shaped routes located to the south of $40^{\circ} \mathrm{N}$ owe their existence to safer, more efficient marine conditions for shipping. Moreover, ocean waves in the $20^{\circ}-40^{\circ} \mathrm{W}$ zone are smaller in the $40^{\circ}-50^{\circ} \mathrm{N}$ region than those in the $50^{\circ}-60^{\circ} \mathrm{N}$ region. This indicates that the third and relatively zonal route along the $20^{\circ}-40^{\circ} \mathrm{W}, 40^{\circ}-50^{\circ} \mathrm{N}$ region is away from dangerous maximum-wave zones. As such, it becomes a regularly-used route for cross-NA shipping.

Seasonal surface circulations over the NA depicted by CFSR SLP and V10 fields are shown in Figs. 9 and 10, respectively. As shown in Fig. 9 the SLP fields feature a prevailing low system in the $50^{\circ}-70^{\circ} \mathrm{N}$ region with a center nearby the Icelandic Islands which is known as the Icelandic low (e.g., Sahsamanoglou 1990; Serreze et al. 1997; Ahrens 2005). This low extends from the northeast to the southwest with dominant well-organized patterns in winter, spring and fall. The positions and pressure values of the low center in the $60^{\circ} \mathrm{W}-0^{\circ}, 50^{\circ}-70^{\circ} \mathrm{N}$ region are shown in Table 1 .
These values disclose that the Icelandic low emerges in an eastward position in fall, enhances with a westward extension in winter, and retreats eastward with a weakened intensity in spring. The Icelandic low vanishes in summer as indicated by an increasing pressure value. The aforementioned interpretation is clearly demonstrated by the spatial patterns of SLP fields in Fig. 9.

For the surface winds, the winter $V 10$ fields (Fig. 10a) show a belt of strong westerly winds in the $40^{\circ}-50^{\circ} \mathrm{N}$ zone. These strong winds are located at the southern periphery of the Icelandic low centering near $62.5^{\circ} \mathrm{N}$ (see Table 1). Similar to the effects exerted by the Aleutian low on the northern $\mathrm{NP}$, the Icelandic low induces strong waves in the NA north of $40^{\circ} \mathrm{N}$ (see Fig. 8a). Following the life cycle of the Icelandic low, mid-latitude westerly winds weaken evidently in spring (Fig. 10b) in concert with the decay in the Icelandic low. The winds change into southwesterly flows in summer in association with the appearance of the subtropical high (Fig. 10c), and reestablish in fall due to the development of the Icelandic low (Fig. 10d). SLP and V10 analysis results demonstrate that the intensity of the Icelandic low and accompanying mid-latitude westerly flows at its southern section are strongest in winter. These flows decline in intensity from spring to their weakest levels in summer. As such, the ocean waves in the regions north of $40^{\circ} \mathrm{N}$ are evidently strong in winter and fall, moderate in spring and weak in the summer (see Fig. 8). In the $20^{\circ}-40^{\circ} \mathrm{W}, 40^{\circ}-50^{\circ} \mathrm{N}$ region where the third (and zonal) route situates, the $V 10$ field in the fall is dominated by westerly flows, which are closely associated with the Icelandic low. On the other hand, winds in spring are jointly affected by both higher-latitude and subtropical circulations, leading to a change in wind direction characterized by southwesterlies in summer. Increases in the influence of the subtropical circulation make the winds warmer, which are less effective in inducing strong ocean waves compared to the cold winds of fall and winter. As such, shipping should be safer and more efficient when it uses the third route in spring and summer than in winter and fall, as indicated by the frequency patterns in Fig. 7 .

Transient activity represented by the RMS of 2-7-day filtered SLP for each season is shown in Fig. 11. Overall, severe weather indicated by strong transient activity ( $\geq 4 \mathrm{hPa}$ ) occurs in the higher latitudes. Strong transient activity shows a southward and southwestward extension from the higher latitudes toward North America, resembling the spatial distributions of ocean waves in Fig. 8. A maximum center appears in the North America-NA conjunction region. It is around Newfoundland in winter (Fig. 11a) and displaces northward to the north of $50^{\circ} \mathrm{N}$ in fall (Fig. 11d). Transient activity weakens in intensity during spring (Fig. 11b) and reduces to its minimum intensity in summer (Fig. 11c). It is clear that transient activity is consistently weak in regions south of $40^{\circ} \mathrm{N}$ throughout the year, providing favorable weather conditions for the prevailing X-shaped routes. The transient 

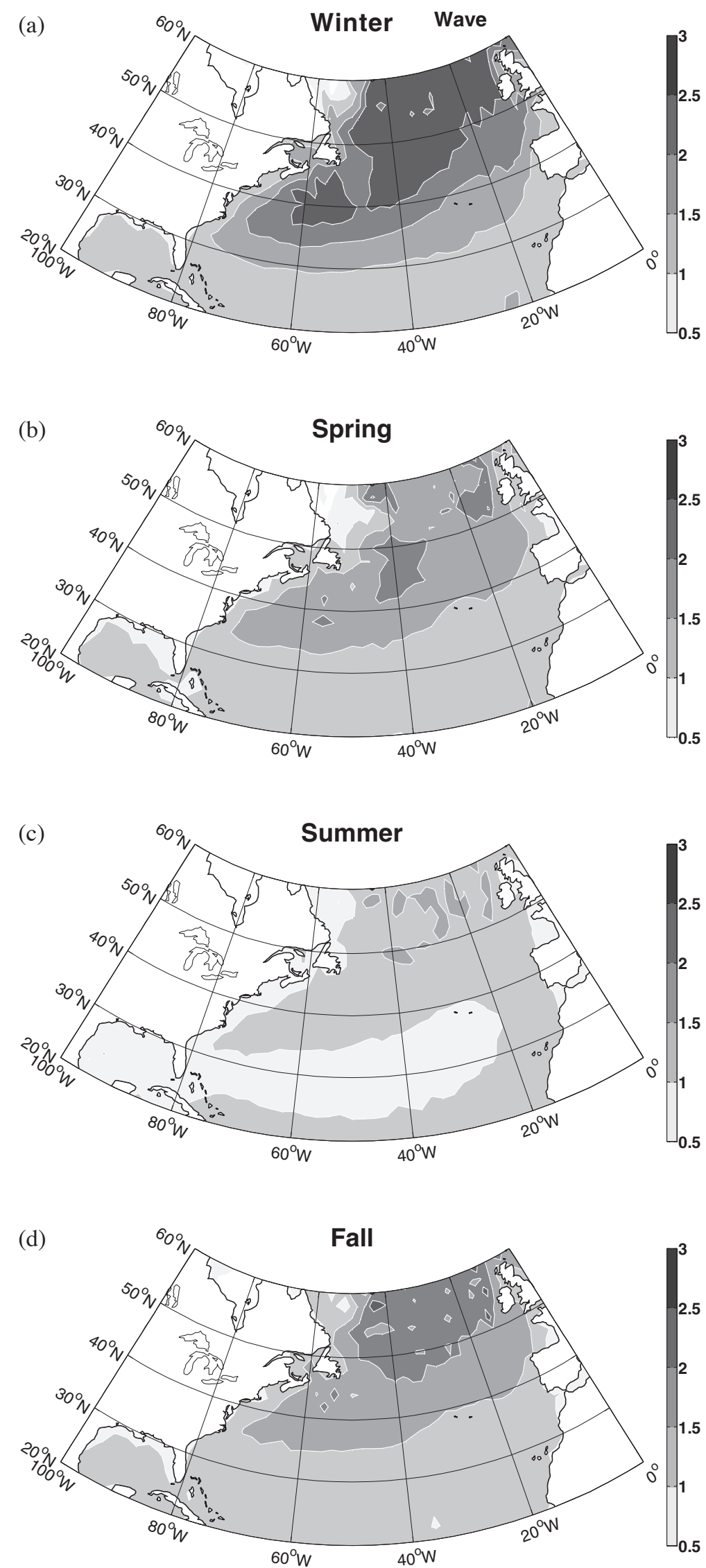

Fig. 8. As in Fig. 7, except for the climatological-mean ocean wave in the NA computed from ICOADS data for (a) winter, (b) spring, (c) summer, and (d) fall. The contour intervals are $0.5 \mathrm{~m}$. 

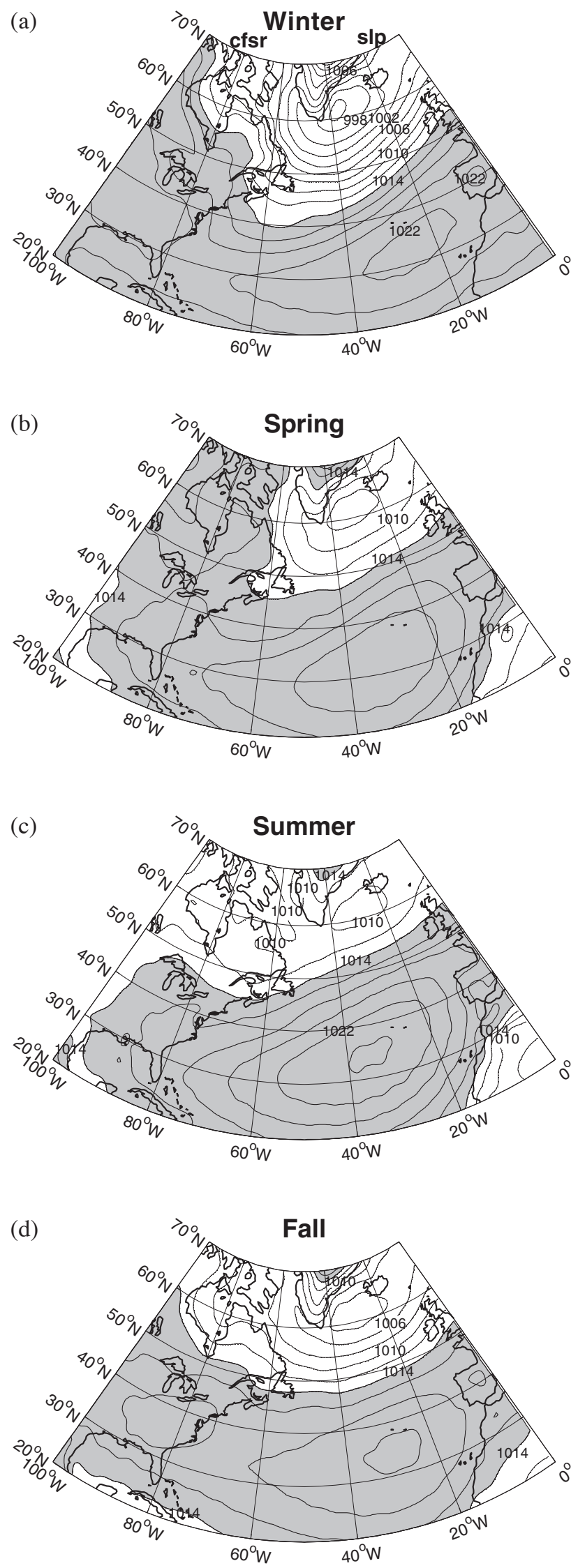

Fig. 9. As in Fig. 7, except for the climatological-mean SLP in the NA computed from CFSR data for (a) winter, (b) spring, (c) summer, and (d) fall. Pressure values larger than $1014 \mathrm{hPa}$ are shaded. The contour intervals are $2 \mathrm{hPa}$. 



Fig. 10. As in Fig. 9, except for the climatological-mean 10-m winds (vector) and their speed (shading) in the NA computed from CFSR data for (a) winter, (b) spring, (c) summer, and (d) fall. The shading has the intervals of $2 \mathrm{~m} \mathrm{~s}^{-1}$. 

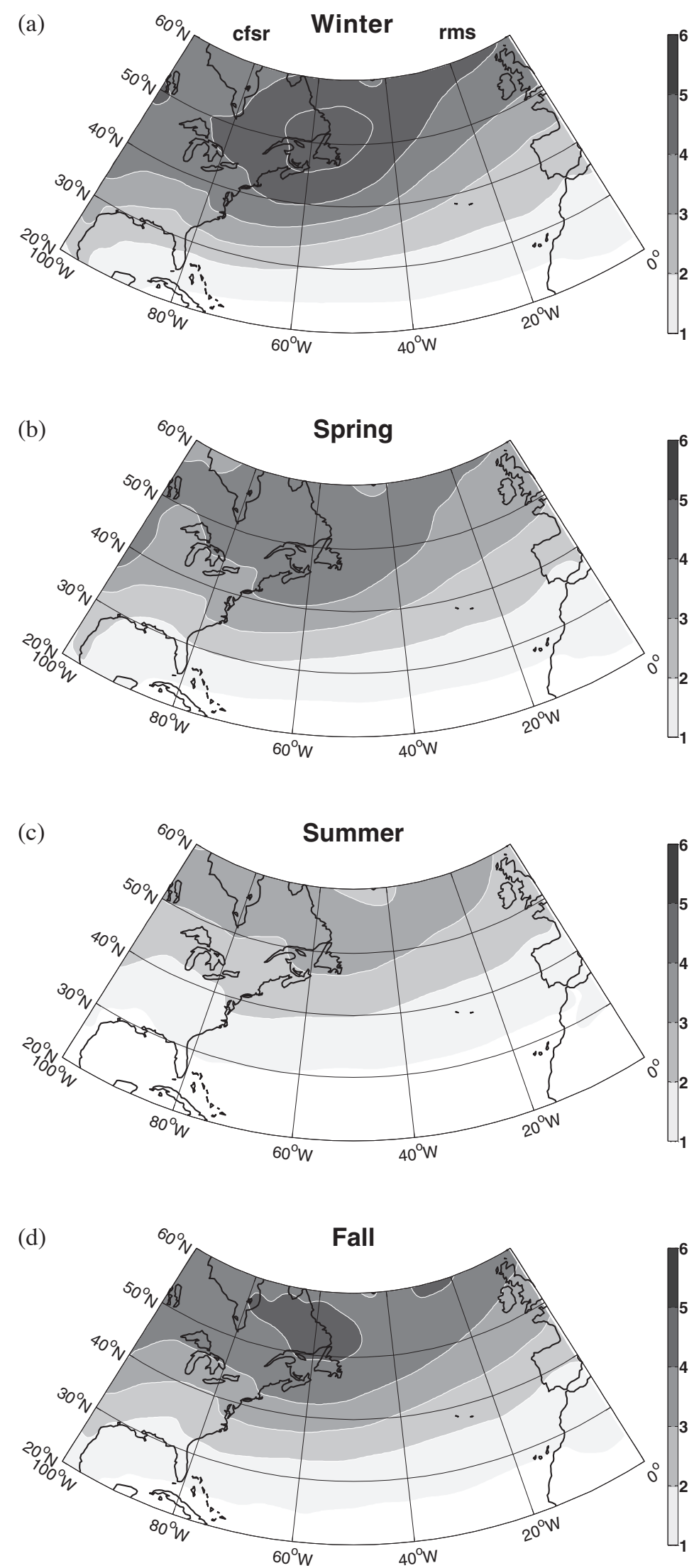

Fig. 11. As in Fig. 9, except for the RMS values of 2-7-day filtered SLP fields in the NA computed from CFSR data for (a) winter, (b) spring, (c) summer, and (d) fall. The contour intervals are $1 \mathrm{hPa}$. 
activity analyses in both the NP and NA show maximum centers to the north of $40^{\circ} \mathrm{N}$ which reach the strongest intensity in winter and the weakest intensity in summer. These results indicate that transient activity analyzed in this study is mainly contributed by the extratropical cyclones in cold seasons, instead of tropical cyclones in summer.

\section{CONCLUDING REMARKS}

Global shipping is a major facilitator of world economic growth. The characteristics of the major shipping routes and their associated modulating factors are thus of importance to shipping safety and economic activity. This study compiled the ICOADS 1981 - 2010 ship-reported data and employed them to analyze major shipping routes and oceanwave conditions in the NP and NA. The climatic features effectively modulating marine conditions and the major shipping routes were analyzed. This study aims to gain a better understanding of the relationship between climate, oceans and shipping routes. The results of this study are helpful in increasing shipping safety and efficiency across the NP and NA.

In the NP, most ships take a great-circle route to cross the basin. This route starts from the coast of East Asia and Japan, heads northeastward along the Kuril Islands to turn eastward nearby the Russian Kamchatka Peninsula, and moves toward North America along oceans at the $54^{\circ} \mathrm{N}$ latitude north of the Aleutian Islands. This route is taken throughout the year for two reasons: efficiency and safety. Due to the Earth's spherical shape, a higher-latitude route is shorter in navigational distance to cross the NP than a lower-latitude route. This reduces navigational time and shipping costs, and thus increases economic benefits. In terms of safety, the central NP is primarily under the influence of the Aleutian low during winter, spring and fall. Strong ocean waves and severe synoptic weather impose high threats to shipping safety in this region. Ships thus move northward to penetrate the central region of the Aleutian low along $54^{\circ} \mathrm{N}$ where winds and ocean waves are weaker than those in the southern section of the Aleutian low south of $50^{\circ} \mathrm{N}$. In summer, the appearance of the Pacific subtropical high over the NP eases marine conditions, leading to weak ocean waves and gentle synoptic weather. With safer climatic conditions two additional cross-NP routes move through the $40^{\circ}-50^{\circ} \mathrm{N}$ zone south of the Aleutian Islands.

In the NA the two most frequent routes exist in the $50^{\circ}-20^{\circ} \mathrm{W}$ zone to form an X-shaped pattern in the oceans south of $40^{\circ} \mathrm{N}$. They cross each other at a common point around $30^{\circ} \mathrm{W}, 38^{\circ}-40^{\circ} \mathrm{N}$. The southwest-northeast oriented route connects the Panama Canal and the British Isles and Europe. The northwest-southeast oriented route extends from the east coast of North America toward the Mediterranean Sea. The X-shaped routes are situated mainly to the south of $40^{\circ} \mathrm{N}$ and prevail throughout the year due to weak ocean waves and winds. It is because they are far from the influences of the Icelandic low and thus imbued with safe and efficient marine environments. A third and more eastwest oriented route appears to the north of the X-shaped routes in the $20^{\circ}-40^{\circ} \mathrm{W}, 40^{\circ}-50^{\circ} \mathrm{N}$ region. It is also generally used all year around, but more frequently in spring and summer than winter and fall due to weaker ocean waves and winds in association with less influence from the Icelandic low in the region during spring and summer.

The major routes crossing the NP and NA and the associated modulating climatic features analyzed in this study exhibit some interesting similarities and discrepancies. In terms of similarities, the major climatic feature affecting the spatial distribution of shipping routes is the Aleutian low in the NP and the Icelandic low in the NA. Both lows have a center at the higher latitudes. They develop in fall, reach their maxima in winter, decay in spring, and vanish in summer. Moreover, the cold westerly flows at their southern sections cause high waves, strong winds, and severe synoptic weather providing dangerous marine conditions for shipping in the mid-latitudes. For the discrepancy, the Aleutian low has a center around $51.5^{\circ} \mathrm{N}$ in winter, while the Icelandic low centers in a more northern region around $61.5^{\circ} \mathrm{N}$. The most affected and dangerous regions are thus to the south of $50^{\circ} \mathrm{N}$ in the NP, but to the north of $50^{\circ} \mathrm{N}$ in the NA. Moreover, it takes much longer navigational distance to cross the NP than the NA. To avoid dangerous conditions and take into account the economic benefits of saving navigational time and shipping costs, a safer and shorter route is highly preferred by the NP shipping, leading to the most frequent routes all year around being toward higher latitudes along the center of the Aleutian low around $54^{\circ} \mathrm{N}$. In the NA, navigational distances are shorter and less of a factor, while safety is the priority. Major shipping routes avoid the Icelandic low-affected regions north of $50^{\circ} \mathrm{N}$ and form an X-shaped pattern in the relatively safe regions over the southern oceans south of $40^{\circ} \mathrm{N}$.

This study illustrated that the major cross-basin routes in both NP and NA are closely related to and modulated by the large-scale features associated with seasonal climatic conditions and marine environments. Due to differences in considerations for shipping safety and economic benefits, seasonal differences in major shipping routes are more evident in the NP than in the NA. It is important to understand the similarities and differences between NP and NA climatic factors and their influences over the economics and safety of shipping routes as this information is valuable to international shipping. Thus far, this understanding has not been systematically documented and acknowledged in the shipping industry. In general, major shipping routes are designed to avoid the most dangerous marine conditions of winter. The same routes may be used through these regions and experience relatively strong winds and waves during spring and fall due to meridional displacements from the 
Aleutian low and Icelandic low. However, while strong winds and waves prevail in spring and fall, they are weaker than those of winter. Thus, these routes are considered relatively safe for shipping.

The Aleutian low and Icelandic low are the two most important features affecting shipping safety. These two lows are found to exhibit evident seesaw oscillations in interannual variability (e.g., van Loon and Rogers 1978; van Loon and Madden 1983). The centers of action of this seesawing in the winter are nearby $160^{\circ} \mathrm{W}, 46^{\circ} \mathrm{N}$ for the Aleutian low and nearby $15^{\circ} \mathrm{W}, 65^{\circ} \mathrm{N}$ for the Icelandic low (e.g., Honda and Nakamura 2001; Honda et al. 2001). An intensified Aleutian low deepens with a southward displacement from its climatological position $\left(51.5^{\circ} \mathrm{N}\right)$. In this case, the major cross-NP routes along $54^{\circ} \mathrm{N}$ should not be highly affected. For the winter Icelandic low, it deepens with a northwarddisplaced center from its climatological position $\left(61.5^{\circ} \mathrm{N}\right)$. The major cross-NA routes south of $40^{\circ} \mathrm{N}$ should not be highly affected. The Aleutian low also exhibits an east-west displacement from one year to the other (e.g., Fritz 1985; Rodionov et al. 2005). We thus separate the 1981 - 2010 winters into two groups based upon the position of the Aleutian low center: to the west of $180^{\circ}$ ( 15 cases) and to the east (15 cases). As shown in Fig. 12, the composite Aleutian low centers of the west and east groups are located nearby $170^{\circ} \mathrm{E}$ and $168^{\circ} \mathrm{W}$, respectively. They are about $10^{\circ}$-longitude displacements from the climatological position $\left(180^{\circ}\right.$, see Table 1). Even with the evident differences in Aleutian low patterns, the composite patterns of winter's major shipping routes (not shown) reveal no noticeable difference between these two groups. These results indicate that general practice in the shipping industry does not place high consideration on climatic factors. Chen et al. (2012) examined total shipping frequency variability in the northern NP along the great-circle route. They found that total shipping frequency exhibits evident interdecadal variability, while interannual variability from ENSO's influences is indiscernible. International trade and economic advantage are more important factors than climatic conditions for present shipping operation. The findings of this study on the relationship between major shipping routes and modulating climatic features should provide systematic knowledge and helpful information for the shipping industry to aid in the choice of safer and more efficient shipping routes, which should lead to better economic benefits.

Acknowledgments The authors would like to thank the anonymous Reviewers for their suggestions and comments which helped to greatly improve the scientific quality of this paper. This study was supported by the National Science Council, Taiwan, under Grants NSC 101-2623-E-022001-D and NSC 101-2111-M-415-001.


Fig. 12. The composite SLP patterns for the years with the Aleutian low center: (a) to the west of $180^{\circ}$, and (b) to the east of $180^{\circ}$. 


\section{REFERENCES}

Ahrens, C. D., 2005: Essentials of Meteorology: An Invitation to the Atmosphere, $4^{\text {th }}$ Ed., Thomson Brooks/Cole, Singapore, $473 \mathrm{pp}$.

Blackmon, M. L., J. M. Wallace, N. C. Lau, and S. L. Mullen, 1977: An observational study of the Northern Hemisphere wintertime circulation. J. Atmos. Sci., 34, 1040-1053, doi: 10.1175/1520-0469(1977)034<1040:AOSOTN>2.0.CO;2. [Link]

Blackmon, M. L. and N. C. Lau, 1980: Regional characteristics of the Northern Hemisphere wintertime circulation: A comparison of the simulation of a GFDL general circulation model with observations. $J$. Atmos. Sci., 37, 497-514, doi: 10.1175/1520-0469(1980)037<0497:RCOTNH>2.0.CO;2. [Link]

Blackmon, M. L., Y. H. Lee, and J. M. Wallace, 1984: Horizontal structure of $500 \mathrm{mb}$ height fluctuations with long, intermediate and short time scales. $J$. Atmos. Sci., 41, 961-980, doi: 10.1175/1520-0469(1984)041<0961:HSOMHF>2.0.CO;2. [Link]

Chen, J. M., C. M. Hsieh, and J. S. Liu, 2012: Possible influences of ENSO on winter shipping in the North Pacific. Terr. Atmos. Ocean. Sci., 23, 397-411, doi: 10.3319/ TAO.2012.03.02.01(A). [Link]

Fritz, S., 1982: Northern Hemisphere $700 \mathrm{mb}$ heights and Pacific Ocean temperatures for winter months. Mon. Weather Rev., 110, 18-25, doi: 10.1175/1520-0493(1982) 110<0018:NHMHAP>2.0.CO;2. [Link]

Fritz, S., 1985: The Aleutian low in January and FebruaryRelation to tropical Pacific sea surface temperature. Mon. Weather Rev., 113, 271-275, doi: 10.1175/15200493(1985)113<0271:TALIJA>2.0.CO;2. [Link]

Gulev, S. K. and L. Hasse, 1998: North Atlantic wind waves and wind stress fields from voluntary observing shipdata. J. Phys. Oceanogr., 28, 1107-1130, doi: 10.1175/15200485(1998)028<1107:NAWWAW>2.0.CO;2. [Link]

Gulev, S. K. and L. Hasse, 1999: Changes of wind waves in the North Atlantic over the last 30 years. Int. J. Climatol., 19, 1091-1117, doi: 10.1002/(SICI)1097-0088(199908) 19:10<1091::AID-JOC403>3.0.CO;2-U. [Link]

Gulev, S. K. and V. Grigorieva, 2006: Variability of the winter wind waves and swell in the North Atlantic and North Pacific as revealed by the Voluntary Observing Ship data. J. Climate, 19, 5667-5685, doi: 10.1175/JCLI3936.1. [Link]

Gulev, S. K., V. Grigorieva, A. Sterl, and D. Woolf, 2003: Assessment of the reliability of wave observations from voluntary observing ships: Insights from the validation of a global wind wave climatology based on voluntary observing ship data. J. Geophys. Res., 108, doi: 10.1029/2002JC001437. [Link]

Honda, M. and H. Nakamura, 2001: Interannual see- saw between the Aleutian and Icelandic lows. Part II: Its significance in the interannual variability over the wintertime Northern Hemisphere. $J$. Climate, 14, 4512-4529, doi: 10.1175/1520-0442(2001)014<4512:ISBTAA>2.0.CO;2. [Link]

Honda, M., H. Nakamura, J. Ukita, I. Kousaka, and K. Takeuchi, 2001: Interannual seesaw between the Aleutian and Icelandic lows. Part I: Seasonal dependence and life cycle.J.Climate, 14, 1029-1042, doi: 10.1175/15200442(2001)014<1029:ISBTAA>2.0.CO;2. [Link]

Horel, J. D. and J. M. Wallace, 1981: Planetary-scale atmospheric phenomena associated with the Southern Oscillation. Mon. Weather Rev., 109, 813-829, doi: 10.1175/1 520-0493(1981)109<0813:PSAPAW>2.0.CO;2. [Link]

Kalnay, E., M. Kanamitsu, R. Kistler, W. Collins, D. Deaven, L. Gandin, M. Iredell, S. Saha, G. White, J. Woollen, Y. Zhu, M. Chelliah, W. Ebisuzaki, W. Higgins, J. Janowiak, K. C. Mo, C. Ropelewski, J. Wang, A. Leetmaa, R. Reynolds, R. Jenne, and D. Joseph, 1996: The NCEP/NCAR 40-year Reanalysis Project. Bull. Amer. Meteorol. Soc., 77, 437-471, doi: 10.1175/1520-0477( 1996)077<0437:TNYRP>2.0.CO;2. [Link]

Kent, E. C., S. D. Woodruff, and D. I. Berry, 2007: Metadata from WMO publication No. 47 and an assessment of Voluntary Observing Ship observation heights in ICOADS. J. Atmos. Ocean. Technol., 24, 214-234, doi: 10.1175/JTECH1949.1. [Link]

Laing, A. K., 1985: An assessment of wave observations from ships in southern oceans. J. Clim. Appl. Meteorol., 24, 481-494, doi: 10.1175/1520-0450(1985)024<0481:AAOWOF>2.0.CO;2. [Link]

Minobe, S. and A. Maeda, 2005: A $1^{\circ}$ monthly gridded seasurface temperature dataset compiled from ICOADS from 1850 to 2002 and Northern Hemisphere frontal variability. Int. J. Climatol., 25, 881-894, doi: 10.1002/ joc.1170. [Link]

Parker, D, E. Kent, S. Woodruff, D. Dehenauw, D. E. Harrison, T. Manabe, M. Mietus, V. Swail, and S. Worley, 2004: The second JCOMM workshop on advances in Marine Climatology (CLIMAR-II). WMO Bulletin, 53, 157-159.

Philander, S. G., 1990: El Niño, La Niña, and the Southern Oscillation, Academic Press, 293 pp.

Rasmusson, E. M. and T. H. Carpenter, 1982: Variations in tropical sea surface temperature and surface wind fields associated with the Southern Oscillation/El Niño. Mon. Weather Rev., 110, 354-384, doi: 10.1175/1520-0493(1982) $110<0354:$ VITSST>2.0.CO;2. [Link]

Rasmusson, E. M. and J. M. Wallace, 1983: Meteorological aspects of the El Niño/Southern Oscillation. Science, 222, 1195-1202, doi: 10.1126/science.222.4629.1195. [Link]

Rayner, N. A., D. E. Parker, E. B. Horton, C. K. Folland, L. V. Alexander, D. P. Rowell, E. C. Kent, and A. 
Kaplan, 2003: Global analyses of sea surface temperature, sea ice, and night marine air temperature since the late nineteenth century. J. Geophy. Res., 108, doi: 10.1029/2002JD002670. [Link]

Rodionov, S. N., J. E. Overland, and N. A. Bond, 2005: The Aleutian low and winter climatic conditions in the Bering Sea. Part I: Classification. J. Climate, 18, 160-177, doi: 10.1175/JCLI3253.1. [Link]

Sahsamanoglou, H. S., 1990: A contribution to the study of action centres in the North Atlantic. Int. J. Climatol., 10, 247-261, doi: 10.1002/joc.3370100303. [Link]

Saha, S., S. Moorthi, H. L. Pan, X. Wu, J. Wang, S. Nadiga, P. Tripp, R. Kistler, J. Woollen, D. Behringer, H. Liu, D. Stokes, R. Grumbine, G. Gayno, J. Wang, Y. T. Hou, H. Y. Chuang, H. M. H. Juang, J. Sela, M. Iredell, R. Treadon, D. Kleist, P. V. Delst, D. Keyser, J. Derber, M. Ek, J. Meng, H. Wei, R. Yang, S. Lord, H. van den Dool, A. Kumar, W. Wang, C. Long, M. Chelliah, Y. Xue, B. Huang, J. K. Schemm, W. Ebisuzaki, R. Lin, P. Xie, M. Chen, S. Zhou, W. Higgins, C. Z. Zou, Q. Liu, Y. Chen, Y. Han, L. Cucurull, R. W. Reynolds, G. Rutledge, and M. Goldberg, 2010: The NCEP Climate Forecast System Reanalysis. Bull. Amer. Meteorol. Soc., 91, 1015-1057, doi: 10.1175/2010BAMS3001.1. [Link]

Serreze, M. C., F. Carse, R. G. Barry, and J. C. Rogers, 1997: Icelandic low cyclone activity: Climatological features, linkages with the NAO, and relationships with recent changes in the Northern Hemisphere circulation. J. Climate, 10, 453-464, doi: 10.1175/1520-044 2(1997)010<0453:ILCACF>2.0.CO;2. [Link]

Shukla, J. and J. M. Wallace, 1983: Numerical simulation of the atmospheric response to equatorial Pacific sea surface temperature anomalies. J. Atmos. Sci., 40, 1613-1630, doi: 10.1175/1520-0469(1983)040 $<1613$ :NSOTAR>2.0.CO;2. [Link]

Smith, T. M. and R. W. Reynolds, 2003: Extended reconstruction of Global Sea Surface temperatures based on COADS data (1854-1997). J. Climate, 16, 1495-1510, doi: 10.1175/1520-0442-16.10.1495. [Link]
Smith, T. M. and R. W. Reynolds, 2004: Improved extended reconstruction of SST (1854-1997). J. Climate, 17, 2466-2477, doi: 10.1175/1520-0442(2004)017 $<2466$ :IEROS $>2.0 . \mathrm{CO}$; . [Link]

Terada, K. and M. Hanzawa, 1984: Climate of the North Pacific Ocean. In: van Loon, H. (Ed.), Climates of the Oceans, Vol. 15, World Survey of Climatology, Elsevier, 431-477.

Tokinaga, H, Y. Tanimoto, S. P. Xie, T. Sampe, H. Tomita, and H. Ichikawa, 2009: Ocean frontal effects on the vertical development of clouds over the western North Pacific: In situ and satellite observations. J. Climate, 22, 4241-4260, doi: 10.1175/2009JCLI2763.1. [Link]

Van Loon, H. and R. A. Madden, 1983: Interannual variations of mean monthly sea-level pressure in January. $J$. Clim. Appl. Meteorol., 22, 687-692, doi: 10.1175/1520 -0450(1983)022<0687:IVOMMS>2.0.CO;2. [Link]

Van Loon, H. and J. C. Rogers, 1978: The seesaw in winter temperatures between Greenland and Northern Europe. Part I: General description. Mon. Weather Rev., 106, 296-310, doi: 10.1175/1520-0493(1978) 106 $<0296$ :TSIWTB $>2.0$. CO;2. [Link]

Wallace, J. M. and D. S. Gutzler, 1981: Teleconnections in the geopotential height field during the Northern Hemisphere winter. Mon. Weather Rev., 109, 784-812, doi: 10.1175/1520-0493(1981)109<0784:TITGHF>2.0 . CO;2. [Link]

Woodruff, S. D., H. F. Diaz, S. J. Worley, R. W. Reynolds, and S. J. Lubker, 2005: Early ship observational data and ICOADS. Clim. Change, 73, 169-194, doi: 10.1007/s10584-005-3456-3. [Link]

Worley, S. J., S. D. Woodruff, R. W. Reynold, S. J. Lubker, and N. Lott, 2005: ICOADS release 2.1 data and products. Int. J. Climatol., 25, 823-842, doi: 10.1002/ joc.1166. [Link]

Zhang, X., J. E. Walsh, J. Zhang, U. S. Bhatt, and M. Ikeda, 2004: Climatology and interannual variability of Arctic cyclone activity: 1948-2002. J. Climate, 17, 2300-2317, doi: 10.1175/1520-0442(2004)017<2300:CAIVOA>2.0.CO;2. [Link] 